\title{
Trapping of mangrove propagules due to density- driven secondary circulation in the Normanby River estuary, NE Australia
}

\author{
Thomas Stieglitz ${ }^{1,2, *}$, Peter V. Ridd ${ }^{1}$ \\ ${ }^{1}$ Marine Geophysical Laboratory, School of Mathematical and Physical Sciences, James Cook University, \\ Townsville, Queensland 4811, Australia \\ ${ }^{2}$ Institut für Biogeographie, Zentrum für Umweltforschung, Universität des Saarlandes, 66041 Saarbrücken, Germany
}

\begin{abstract}
The dispersal of mangrove propagules in the Normanby River estuary is dominated by secondary estuarine circulation. On flood tides, an axial surface convergence forms midstream, generated by a density-driven circulation cell. Floating material including mangrove propagules is trapped in the convergence, and moves upstream. On ebb tides, the circulation cell reverses, and propagules move towards the banks, where water velocities are much smaller than midstream. Over a tidal cycle, a net upstream drift of propagules occurs. This displacement effect occurs throughout the tropical dry season. Buoyant propagules of Rhizophora stylosa, Bruguiera gymnorrhiza, Xylocarpus mekongensis and Heritiera littoralis have been found to be transported upstream at a speed comparable to a net average speed of $3.2 \mathrm{~km} \mathrm{~d}^{-1}$, found in a drift-drogue experiment. The propagules subsequently accumulate in large numbers in hydrodynamic traps upstream from the convergence and, more importantly, upstream from the mangrove fringe. The hydrodynamic trapping conflicts with the temporal and spatial requirements of propagules to 'find' a habitat suitable for development.
\end{abstract}

KEY WORDS: Mangroves · Propagules · Estuarine circulation · Salinity gradient · Convergence • Dispersal

\section{INTRODUCTION}

The spatial distribution of mangroves has received much attention since the early years of mangrove research. A number of different factors have been identified as influencing growth patterns on worldwide, regional and local scales. Globally, mangroves occur along tropical (and subtropical) coastlines in 2 hemispheres, the Atlantic East Pacific ('New World') and the Indo West Pacific ('Old World'), with almost no species overlap (e.g. Chapman 1976, Duke 1992). On a regional or inter-estuary scale, distribution of mangroves, expressed as species richness or diversity, has been related to geomorphologic (e.g. Wells 1995) and climatic (e.g. Chapman 1976, Lugo \& Zucca 1977, Tomlinson 1986, Smith \& Duke 1987, Wells 1995) factors. A comprehensive analysis by Smith \& Duke

*E-mail: thomas.stieglitz@jcu.edu.au
(1987) compared a suite of environmental parameters to species richness. For East Australian mangroves, a positive correlation of species richness was found to exist with maximum and minimum temperature, catchment area and estuary length, and negative correlation with tidal amplitude, rainfall variation and cyclone frequency (Smith \& Duke 1987). On a local or intra-estuary scale, salinity and tidal inundation have been widely quoted as main factors influencing growth patterns of species ('zonation') (e.g. Watson 1928, Macnae 1969, Chapman 1976, Bunt et al. 1982, Ball 1998). Distribution and growth of species have also been related to sedimentation, physico-chemical factors and ecophysiological adaptation mechanisms (e.g. Boto \& Wellington 1984, Boto et al. 1984, Ball 1998).

Those determinants for the growth of an individual tree as well as the distribution of species generally refer to a mature tree or population, and 'assume' successful early life stages, i.e. dispersal and establish- 
ment (McGuinness 1997). Although it is widely recognised that the dispersal mechanism of a plant has a large effect on distribution on worldwide and regional scales (e.g. Ridley 1930, van der Pijl 1969), in mangroves dispersal is often regarded as having no significant influence on global, regional or local variation in distribution (e.g. Saenger 1982, Smith 1992). The aspects of the dispersal and recruitment mechanisms in mangroves have rarely been studied. Of these, it is mainly the biotic aspects such as propagule development and abundance, propagule predation and establishment that have received attention (Rabinowitz 1978a,b, Saenger 1982, Smith 1988, Clarke 1993, 1995,

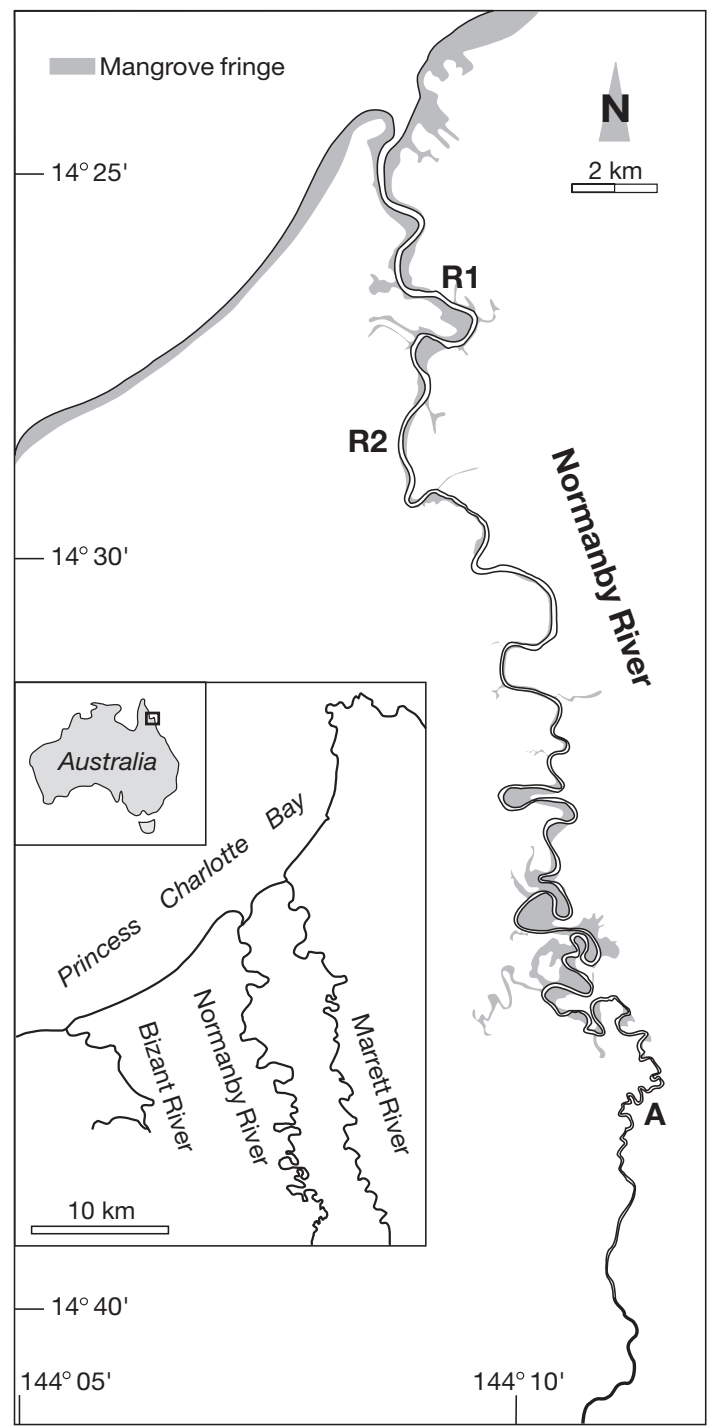

Fig. 1. Geographical location of Normanby River estuary, NE Queensland. Drift buoys were released from Points R1 and R2. A: area of trapping of a large number of mangrove propagules upstream from mangrove habitat (photo in Fig. 8b was taken at A)
McKee 1995, Clarke et al. 2001). Mangroves share the common feature of buoyancy of the reproductive organ, which is an ecological response to life in the tidal environment (Chapman 1976, Tomlinson 1986). The ability of mangrove fruits, seeds and seedlings to float, together with the viviparity of some species are mechanisms widely regarded as being dominant in controlling the dispersal of mangroves (e.g. Chapman 1976, Saenger 1982, Murray 1986, Clarke et al. 2001).

The temporal and spatial distribution of mangrove propagules, however, is not only determined by biotic factors, but also by abiotic factors such as the hydrodynamics of tides and surface currents. The dispersal 'agent', water flow, has received very little attention to date. Tidal sorting of propagules has been suggested to influence zonation of mangrove species in Panama (Rabinowitz 1978a); however, this model has received little support (Saenger 1982, Smith 1992). De Lange \& de Lange (1994) indicated that the hydrodynamics behind propagule dispersal seem to constitute a more important control than climatic factors for the distribution of the only mangrove in New Zealand, Avicennia marina. Clarke (1993) described the predominantly short and rarely long distance dispersal of $A$. marina in southeastern Australia arising from tidal movement. Most recently, Clarke et al. (2001) have partially related effects of propagule dispersability and establishment to patterns of mangrove distribution along estuaries. The change in species distribution and relative abundance during early life stages, i.e. dispersal and establishment, is likely to contribute to the development of growth patterns in a mangrove forest (McKee 1995). The (combined ecological and statistical) chance of a propagule arriving at an ecologically 'suitable' location for growth is therefore likely to play an important role in the establishment of a mature plant, particularly in a disturbed area (McGuinness 1997, Bunt \& Stieglitz 1999). Hence, water flow, and in particular estuarine circulation patterns, may have a significant effect not only on the dispersal of propagules, but also on the distribution of mature trees.

In this work, the entrapment of buoyant propagules by hydrodynamic means in the Normanby River estuary (NE Australia) is investigated, and its effect on mangrove propagule dispersal and species distribution is discussed.

\section{MATERIALS AND METHODS}

Study site and hydrodynamics. The Normanby River discharges into Princess Charlotte Bay at $14^{\circ} 24^{\prime} \mathrm{S}$, $144^{\circ} 8^{\prime} \mathrm{E}$ (Fig. 1). The river forms the eastern boundary of Lakefield National Park, and its mangrove zone is remote from human impact. Its estuary is approxi- 
mately $50 \mathrm{~km}$ in length, and meanders across an extensive low-lying Chenier plain. The tidal regime in the estuary is semi-diurnal and mesotidal, with a maximum tidal range of ca $2.5 \mathrm{~m}$ on spring tides and a minimum tidal range $<1 \mathrm{~m}$ on neap tides. Typical for the tropical region in Northern Australia, the Normanby River is strongly ephemeral, with freshwater discharge usually restricted to the period from January to March (Fig. 2). The hydrodynamics of the estuary have been described in detail in Bryce et al. (1998) and Ridd et al. (1998). Fringing mangroves occur from the mouth to ca $45 \mathrm{~km}$ upstream, with the fringe being most extensive in actively migrating meanders. Twenty different species of mangroves occur, with varying along-river distributions. The growth pattern of zonal species along the river and along riverbank perpendicular transects are described in Bunt \& Stieglitz (1999). No uniform zonation pattern was found to exist along this estuary.

In well-mixed estuaries like the Normanby River estuary, an axial convergence can occur in midstream due to an interaction of the cross-river gradient in axial velocity with the axial density gradient (Nunes \& Simpson 1985). Because of frictional effects, the axial velocity is slower near the channel banks than in its centre, and thus on flood tides the advection of the axial salinity gradient causes a greater density in midstream than at the banks. The central water sinks, causing a 2-cell circulation with an axial convergence zone at the midstream water surface (Fig. 3). Midstream, the convergence is delineated by an unbroken line of accumulated floating matter. On ebb tides the circulation direction is reversed, causing an axial surface divergence with floating material moving to the channel banks. Studies have described density-driven axial convergences for temperate estuaries (Nunes \& Simpson 1985, Robinson Swift et al. 1996), without investigating their potential influence on displacement of organic matter, pollutants, etc. Ridd et al. (1998) observed a density-driven estuarine circulation with an axial convergence zone to occur in the Normanby River estuary, NE Australia, and proposed (but did not

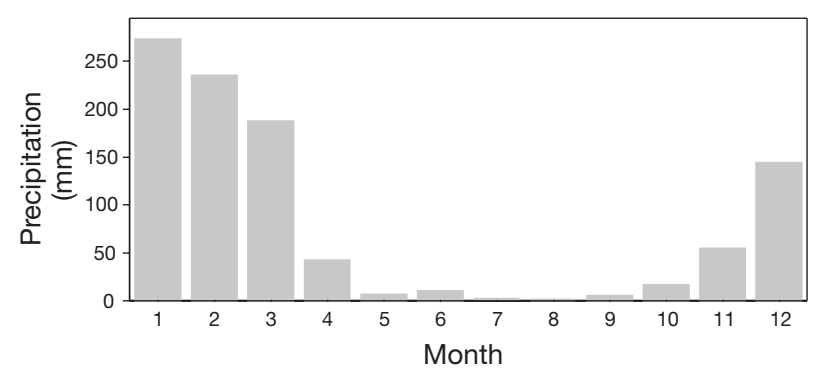

Fig. 2. Average monthly precipitation in the catchment area of the Normanby River (data supplied by Australian Bureau of Meteorology, Weather Station Laura)

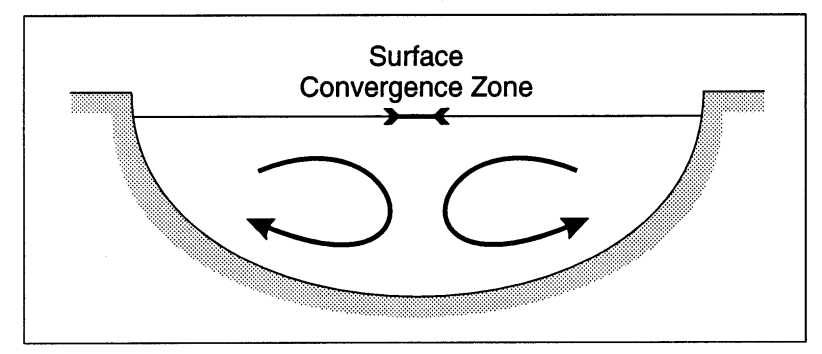

Fig. 3. Secondary circulation cell with axial convergence zone caused by interaction of cross-river gradient in axial velocity with an axial density gradient (from Ridd et al. 1998)

measure) a net upstream displacement of floating organic matter including mangrove propagules by this mechanism. Such proposed drift movement is studied in detail in this paper, with special reference to propagules of selected mangrove species.

Axial salinity transect. Axial surface-salinity transects were sampled at the end of the wet season (April 1998), in the middle of the dry season (September 1998), and at the end of the dry season (December 1997). Salinity in a transect was recorded by taking water samples every 2 to $5 \mathrm{~km}$ along the estuary. The position of sampling was determined with a GPS unit and with 1:100000 scale topographic maps, with an estimated (instrumental) error in position of $\pm 100 \mathrm{~m}$. After a transect was completed, the salinity of each sample was measured to an accuracy of \pm 0.1 with a TPS WP-84 probe, which had previously been calibrated with a commercial salinity standard.

Drift drogues. Twenty-five drogues each were released from Points R1 and R2 (Fig. 1); each drogue consisted of a polystyrene float (diam. $12 \mathrm{~cm}$ ) weighed down with ca $0.5 \mathrm{~kg}$ of chain to reduce wind drift. Drift and float behavior had previously been compared with that of floating organic matter such as mangrove propagules and found to represent the drift behavior of the latter. Wind-generated waves or wind-drift seem to have had a negligible influence on dispersal of both drogues and propagules. The drogues were released at slack low tide close to the banks to simulate their entering of the estuary during the previous falling tide. Their drift paths were observed during the rising tide. Experiments were carried out on a tide with a tidal range of ca $2 \mathrm{~m}$. To investigate the long-term fate of the drogues, drogue positions were observed for $5 \mathrm{~d}$ after release.

Sampling of floating organic matter from the convergence. Floating matter accumulated in the convergence was collected using 2 nets with a width of $42 \mathrm{~cm}$ each attached to the sides of a boat. By slowly crossing the convergence line, usually 20 times over its full width, a representative sample of the floating matter at 

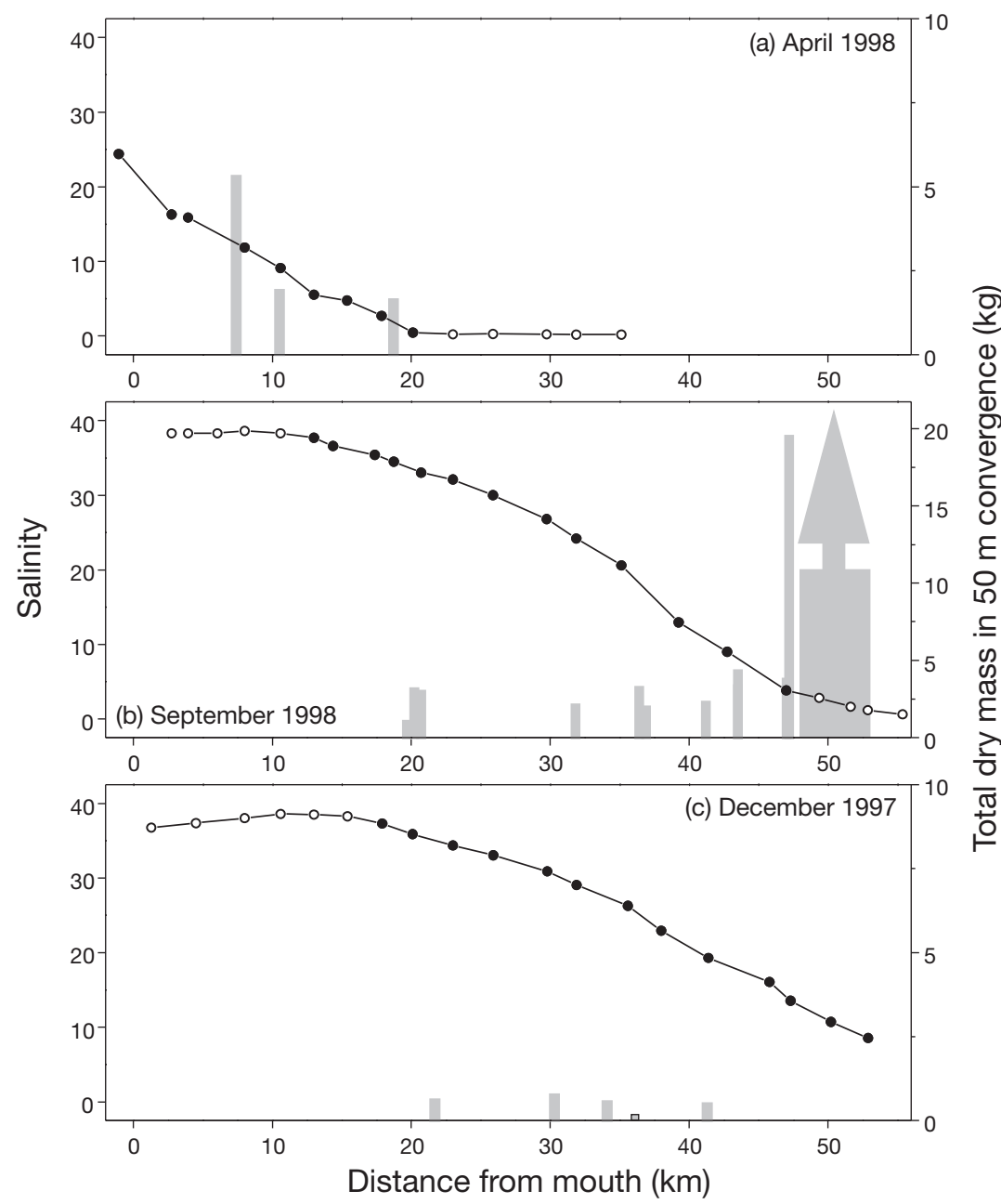

Fig. 4. Axial salinity transect in Normanby River estuary at different times of the year together with total dry mass of organic matter trapped in the axial convergence. (๑) Presence of the axial convergence in the salinity transect; arrow from 48 to $53 \mathrm{~km}$ in (b) indicates trapping of a large amount of floating matter in upstream parts of the estuary. Note different scales on $y$-axes

samples and counted. The 4 species have in common a comparatively large propagule size, which (1) guarantees a representative sample when collecting with nets, and (2) has been found to be positively correlated to buoyancy (Saenger 1982, Clarke et al. 2001), i.e. their propagules tend to display longer buoyancy than the smaller-sized propagules of other species (Saenger 1982, Murray 1986).

Other attributes are (see also Table 1): Rhizophora stylosa is abundant, with a distribution from 0 to $35 \mathrm{~km}$ along the estuary (Bunt \& Stieglitz 1999, see also Fig. 5). It fruits throughout the year (Lovelock 1993), which makes it an interesting species to investigate with respect to longterm dispersal. Longevity of its propagules is up to 2 mo (Murray 1986), in rare cases 6 mo. The propagules generally float in both salt- and freshwater (Clarke et al. 2001), and normally sink after a period of a few weeks. This could be related to predation (Smith 1988), or to their reaching of maximum longevity, or to other factors (Saenger 1982). (Note that the hybrid $R . x$ lamarckii occurs in rare stands on the Normanby River [frequency ratio $R . x$ lamarckii/R. stylosa $=$ 0.02/0.26: Bunt \& Stieglitz 1999]; although the propagules we collected are most likely to be $R$. stylosa, it is possible that some stemmed from $R . x$ lamarckii. Herein, both species are treated as 1 entity.) Bruguiera gymnorrhiza occurs over the full length of

each location could be collected. An effective length of axial convergence of $20 \times 2 \times 0.42 \mathrm{~m}=16.8 \mathrm{~m}$ was sampled. The collected matter was air-dried for $1 \mathrm{mo}$, and the dry mass was determined. All results were normalized to a length of $50 \mathrm{~m}$. The locations for sampling were determined arbitrarily to eliminate subjective influence on the result. In April 1998, 3 samples were taken; in September 1998, 10 samples; and in December 1997, 5 samples. At each sampling point, the salinity was determined. The location of each sampling point in Figs. $4 \& 5$ is given in respect to the salinity gradient, and not in respect to geographic location, i.e. tidal advection was taken into account.

For some detailed investigations, Rhizophora stylosa, Bruguiera gymnorrhiza, Xylocarpus mekongensis and Heritiera littoralis propagules were extracted from the the mangrove fringe (Fig. 5), and fruits from April to July, i.e. the first half of the dry season (Lovelock 1993). Clarke et al. (2001) describe the propagules as floating in saltwater with a tendency to sink in freshwater.

Table 1. Summary of properties of selected mangrove propagules relevant to this study

\begin{tabular}{|c|c|c|c|}
\hline Species & $\begin{array}{l}\text { Fruiting } \\
\text { period }^{\mathrm{a}}\end{array}$ & $\begin{array}{c}\text { Buoyant } \\
\text { in...water }\end{array}$ & $\begin{array}{l}\text { Longevity } \\
(\mathrm{mo})^{\mathrm{C}}\end{array}$ \\
\hline Rhizopora stylosa & All year & Salt/fresh & $0-2$ \\
\hline Bruguiera gymnorrhiza & Apr-Jul & Salt/fresh & $4-9$ \\
\hline Xylocarpus mekongensis & Dec-Feb & Salt/fresh & $6-8(?)$ \\
\hline Heritiera littoralis & Sep-Nov & Salt/fresh & $7-9$ \\
\hline
\end{tabular}



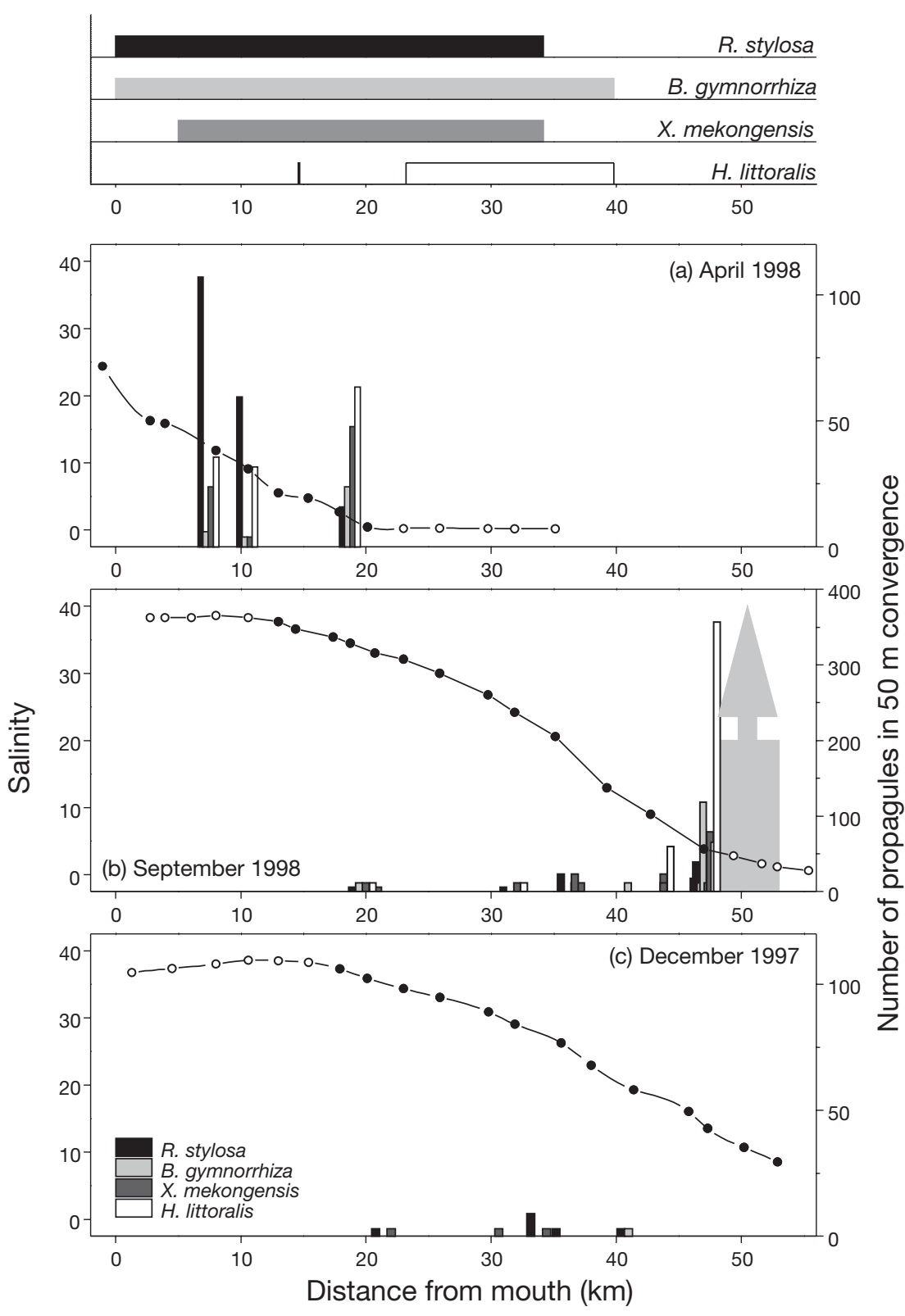

Fig. 5. Axial salinity transect in Normanby River estuary at different times of the year, together with number of propagules of selected species trapped in the axial convergence. ( $\bullet$ Presence of the axial convergence in the salinity transect; arrow from 48 to $53 \mathrm{~km}$ in (b) indicates trapping of a large number of propagules in upstream parts of the estuary. Top graph: distribution of selected species along the river (from Bunt \& Stieglitz 1999). (Full specific names in Table 1). Note different scales on $y$-axes

Xylocarpus mekongensis and Heritiera littoralis are non-viviparous, with both types of propagules floating for long periods of time, i.e. up to or even longer than 1 yr (Murray 1986). This trait makes them most suitable for the investigation of long-term dispersal. The mature trees of both species tend to occur in the middle and upper parts of the estuary (Fig. 5). X. mekongensis fruits in the wet season (December to February), and $H$. littoralis just before the wet season (September to November) (Lovelock 1993). Both seeds float in both salt- and freshwater (Clarke et al. 2001) and have a viability of 6 to 9 mo. Together, these 4 species cover a whole range of fruiting times, occurrence along the estuary, and propagule traits.

Visual observations. An axial convergence zone was visually identifiable by a marked accumulation of leaf litter and other material floating in a well-defined area near midstream together with a negligible amount of litter towards the banks (see Fig. 7). Movement and accumulation of floating matter, in particular propagules, was visually observed during a period of ca $1 \mathrm{wk}$ each in December 1997 and April and September 1998. 


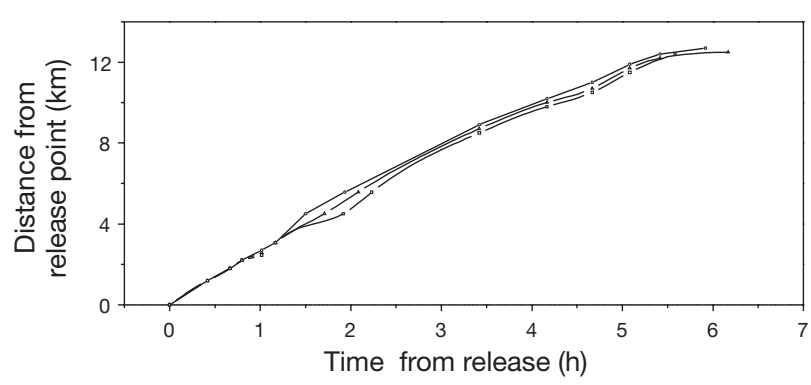

Fig. 6. Trajectories of 3 representative drogues transported upstream in the axial convergence during 1 tidal cycle

During the tropical wet season (January to March) 1999, Lakefield National Park staff noted locations and movements of big accumulation-patches of floating matter observed during routine field trips. Other than observations on the convergence zone, visual data are not presented in the results section. Where appropriate, they are mentioned in the 'Discussion'.

\section{RESULTS}

\section{Axial salinity transects and visual observations of the convergence zone}

Axial salinity transects taken at high water at different times of the year are shown in Figs. $4 \& 5$. At the end of the wet season, a strong freshwater influence was obvious, with freshwater reaching $20 \mathrm{~km}$ upstream from the river mouth. In the middle of the dry season, salinity was constant up to ca $12 \mathrm{~km}$ upstream, and dropped monotonically to 0 at ca $55 \mathrm{~km}$ upstream. At the end of the dry season, an evaporation-driven salinity maximum occurred ca 10 to $15 \mathrm{~km}$ upstream, and the intrusion of salt reached further than $55 \mathrm{~km}$ into the estuary. An axial convergence was consistently and exclusively observed on flood tides at locations where the axial salinity gradient was $>0.5 \mathrm{~km}^{-1}$ (Figs. 4 \& 5). The along-river location and extension of the convergence zone varied with the prevailing salinity gradient. At the end of the wet season, the convergence extended from the mouth to $20 \mathrm{~km}$ upstream, in the middle of the dry season from 15 to ca $48 \mathrm{~km}$, and at the end of the dry season from $20 \mathrm{~km}$ to $>55 \mathrm{~km}$ upstream.

\section{Drift drogues}

At the onset of rising tide, the drift drogues released close to the banks at Points R1 and R2 were transported into the convergence by the cross-river compo- nent of the surface current, and moved upstream in 'clusters' (areas of $50 \mathrm{~m}$ diam.) in due course. The trajectories of 1 drogue from each of the 3 clusters are shown in Fig. 6. About $3.5 \mathrm{~km}$ upstream from the release point (i.e. $1.3 \mathrm{~h}$ after release), the drogues encountered a significant turbulence at a river bend, which separated the drogues previously floating together. All, however, stayed within the axial convergence zone. About $6 \mathrm{~h}$ after release, high water was reached. The direction of the circulation reversed soon after the turn of the tide, and the drogues floating in midstream together with other floating matter were driven towards the bank, where they were stranded as the water level dropped. During the following low tide, the drogues stayed on the muddy bank or in eddies behind obstacles such as mangrove roots, and did not move downstream. The drogues traveled a mean distance of ca $12 \mathrm{~km}$ in an upstream direction during 1 tidal cycle. They were picked up by the following rising tide, transported into the convergence by the cross-river component of the surface current, and moved further upstream.

The upriver speed of 16 drogues averaged over $5 \mathrm{~d}$ is shown in Table 2. These data take into account the combined effects of upriver movement in the convergence during each rising tide, and trapping of the drogues on the bank at each falling tide during the observation period. Four drogues were permanently trapped in eddies, and did not move at all or very little. The maximum daily excursion was as much as $14 \mathrm{~km}$, i.e. a full tidal excursion. The mean daily speed averaged over the 16 drogues and $5 \mathrm{~d}$ was $3.2 \pm 3.9 \mathrm{~km} \mathrm{~d}^{-1}$. Of the 50 released drogues, 5 were trapped in a root or snagged by their chain. The trajectories of these drogues have not been included in the data, since they do not represent the behavior of natural floating matter. The majority of released drogues were not found during the surveys, possibly because the survey did not extend further than $45 \mathrm{~km}$ into the estuary. It is very likely that the missing drogues drifted far further upstream than initially anticipated, and therefore were not found at the time of the survey. Thus, the calculated average speed of $3.2 \mathrm{~km} \mathrm{~d}^{-1}$ is likely to be a very conservative estimate of the upriver drift speed, and to include only the 'slower' drogues. Drogues were never found downstream of their release point.

\section{Organic matter trapped in the axial convergence}

At the end of the wet season, the dry mass of accumulated floating matter tended to decrease with distance from the mouth, from $5.3 \mathrm{~kg}$ per $50 \mathrm{~m}$ convergence at $7.4 \mathrm{~km}$ to $1.65 \mathrm{~kg}$ per $50 \mathrm{~m}$ at $18.7 \mathrm{~km}$ upstream of the mouth (Fig. 4a). In the middle of the 
Table 2. Net upstream speed of drogues averaged over $5 \mathrm{~d}$ of observation

\begin{tabular}{|lcc|}
\hline Buoy no. & $\begin{array}{c}\text { Release } \\
\text { point (Fig. 1) }\end{array}$ & $\begin{array}{c}\text { Average net upstream } \\
\text { speed }\left(\mathrm{km} \mathrm{d}^{-1}\right)\end{array}$ \\
\hline A1 & R1 & 0.06 \\
A2 & R1 & 0.20 \\
A3 & R1 & 3.32 \\
A4 & R1 & 1.96 \\
A5 & R1 & 14.60 \\
B1 & R2 & 1.43 \\
B2 & R2 & 2.91 \\
B3 & R2 & 4.00 \\
B4 & R2 & 2.21 \\
B5 & R2 & 2.92 \\
B6 & R2 & 0.06 \\
B7 & R2 & 2.20 \\
B8 & R2 & 0.06 \\
B9 & R2 & 0.87 \\
B10 & R2 & 10.54 \\
B11 & R2 & 4.00 \\
Avg. & & $3.2 \pm 3.9$ \\
\hline
\end{tabular}

dry season, the dry mass density was, with 2 to $4 \mathrm{~kg}$ per $50 \mathrm{~m}$, relatively constantly distributed over most of the length of the convergence (Fig. 4b); however, at the upstream end of the convergence, $19.5 \mathrm{~kg}$ per $50 \mathrm{~m}$ dry mass was accumulated in the $50 \mathrm{~m}$ convergence, a factor of at least 5 higher than at downstream locations. At the end of the dry season, very little floating matter, i.e. $<1 \mathrm{~kg}$ per $50 \mathrm{~m}$, was found in the convergence (Fig. 4c). The upstream end of the convergence was not surveyed at the time. The number of propagules in the $50 \mathrm{~m}$ convergence varied across species and seasons (Fig. 5). Generally, the highest accumulation of all species occurred at the upstream end of the convergence, furthest away from the mouth of the estuary, with the exception of Rhizophora stylosa propagules, which were most abundant close to the mouth at the end of the wet season (Fig. 5a).

\section{Visual observations}

The samples of floating matter and propagules taken from the convergence quantitatively represent what could be visually observed along the river. A large amount of floating matter was seen to accumulate in an almost unbroken line along the estuary (Fig. 7), wherever the axial salinity gradient was large enough to support the formation of a circulation cell, i.e. $>0.5 \mathrm{~km}^{-1}$. In the middle of the dry season, a large amount of floating matter, including literally thousands of propagules of Heritiera littoralis and a considerable number of other species, was found in hydrodynamic traps such as snags and eddies in an area of ca $5 \mathrm{~km}$ length upstream from the upstream end of the convergence, where the river water is fresh. The photo in Fig. 8b, taken at Position A (Fig. 1), shows an example of an accumulation of trapped mangrove propagules and leaves in the terrestrial habitat. Some of those 'seed and leaf rafts' are $>0.5 \mathrm{~m}$ thick and extend over areas in the order of tens of square meters. The overall number of propagules and the size of these areas made it difficult to obtain a representative sample. The shaded arrow in Figs. $4 \& 5$ indicates the position (and numbers) of the extraordinarily large number of propagules observed. It was impossible for the authors to make observations on propagule dispersal during wetseason flood events. However, limited observations were made by Lakefield National Park staff. A large number of $H$. littoralis seeds was reported floating at a distance of ca $30 \mathrm{~km}$ upstream from the mouth in February 1999, and $20 \mathrm{~km}$ upstream in mid-March 1999.

\section{DISCUSSION}

\section{Short-term drift of propagules and trapping in upper parts of the estuary}

On a tidal/daily scale, a considerable net upstream movement was displayed by drogues, propagules and other floating matter. The most notable accumulation of propagules of all investigated species was found in the middle of the dry season at the upstream end of the convergence (Fig. 8a) and in even larger numbers in hydrodynamic traps just upstream (Fig. 8b). Both areas lie 8 to $48 \mathrm{~km}$ upstream of mature stands of different species, i.e. potential sources of propagules (Fig. 5). Therefore we conclude that propagules are almost exclusively transported upstream at times when a long salinity gradient of $\geq 0.5 \mathrm{~km}^{-1}$ is present, forming density-driven axial convergence zones, and that the propagules are retained in the upper reaches of the estuary by the convergence zone and turbulences, both being efficient hydrodynamic traps.

\section{Long-term dispersal of propagules}

In the seasonal Normanby River, density-driven axial convergences are present for most of the year, i.e. throughout the dry season (Figs. 4 \& 5). Hence, propagules released from parent trees during this period are likely to be trapped by the convergence and kept within the estuarine system. Generally, at any time, the largest accumulation of propagules is expected to occur at the upstream end of the axial convergence, where water salinity is close to zero (Figs. 5 


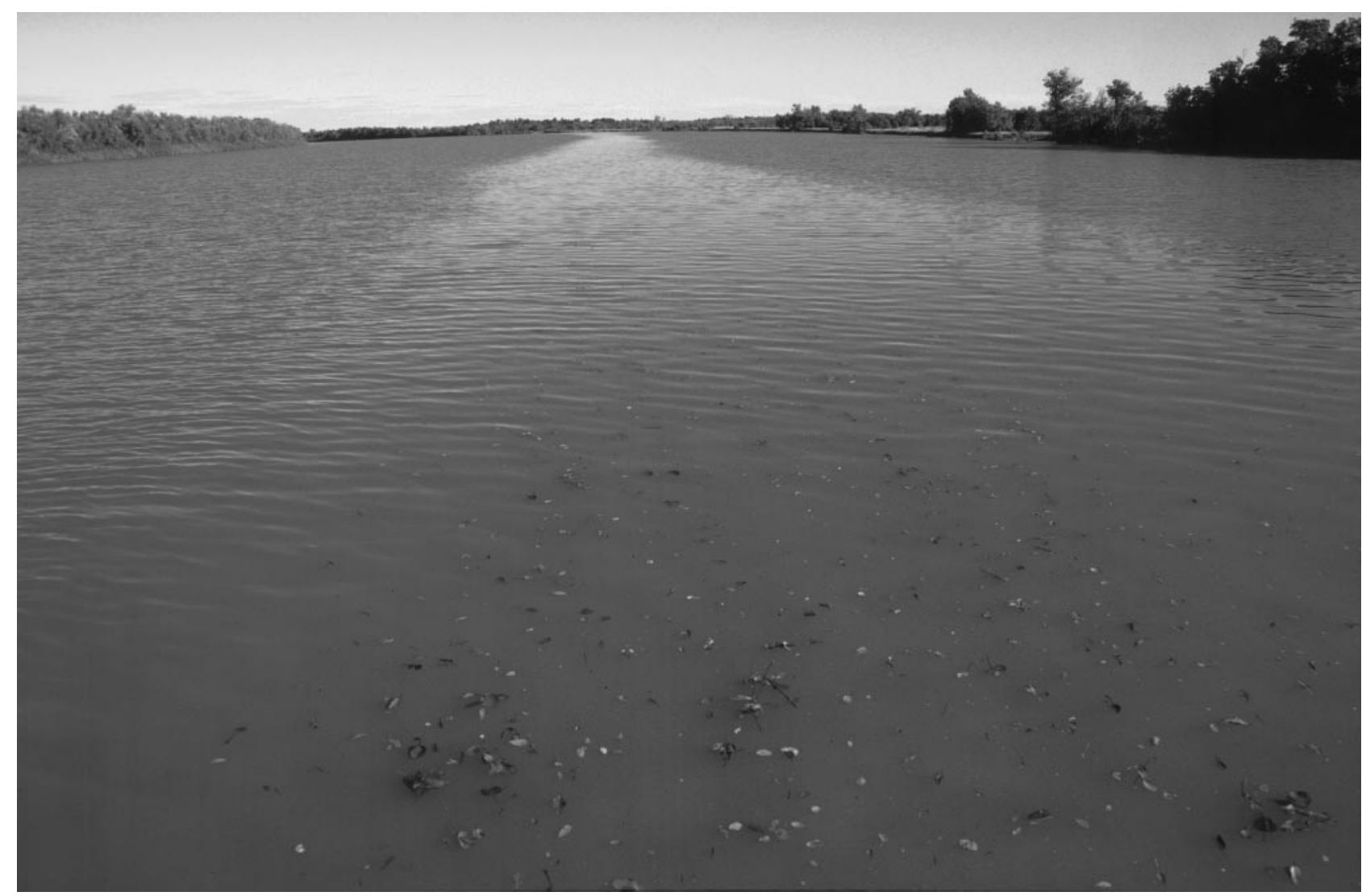

Fig. 7. Midstream axial convergence at flood tide in Normanby River estuary. The convergence is delineated by a line of trapped floating matter

\& 8a). This has been observed for all species at the end of the wet season and the middle of the dry season, except for Rhizophora stylosa at the end of the wet season (Fig. 5a); this exception is likely to have been the result of a release of a relatively high number of propagules from parent trees at this particular time.

At the end of the dry season, the upstream end of the convergence, i.e. the furthest saline extension, lies further upstream than $60 \mathrm{~km}$ from the mouth, in an area that we were unable to survey. It is reasonable to infer that the highest accumulation of propagules occurs at the upstream end of the convergence also at the end of the dry season. During the dry season, the initially steep salinity gradient slowly moves upstream and 'spreads', as freshwater input ceases and baroclinic circulation and evaporation increase salinity (compare April to December transects in Figs. 4 \& 5; see also Wolanski 1986). The furthest extension of the convergence zone into the estuary moves upstream with time, and with it the trapped propagules (Fig. 5). In the middle of the dry season, the propagules are trapped upstream of the mangrove habitat (Fig. 8b). The end of the convergence and propagule traps lie within an area where the mangrove fringe is replaced by terrestrial vegetation (Fig. 1).

With sufficiently high freshwater input into the estuary during the wet season, the estuary can become fresh to its mouth. Over the past few years, this has been observed by local fishermen to happen for a short period of time in the order of days or weeks, in some years on 2 or 3 occasions, during the wet season (J. Barton pers. comm.). Convergences do not form during this time, and propagules are no longer trapped in upstream parts of the estuary, and can progress downstream. Only during this period of rapid flow downstream (current speeds of $2 \mathrm{~m} \mathrm{~s}^{-1}$ have been observed by one of the authors [Stieglitz] to occur in the Normanby River in wet-season floods), can propagules potentially leave the estuary. This wet season 'outwelling' of propagules stemming from estuarine mangroves is likely to contribute to Heritiera littoralis and other typically estuarine propagules being washed up on beaches along the North Queensland coast. However, floating propagules encounter large-scale eddies whilst floating downriver in floods at a speed far less than the downstream 
water speed. The data presented here indicate that propagules do move downstream during the wet season, but do not necessarily leave the estuary in every wet season. In April 1998, after a moderately 'strong' wet season, a considerable number of $H$. littoralis propagules were found at the upstream end of the newly formed convergence (Fig. 5). These propagules had been released from the trees before the wet season (see Table 1), and therefore did not leave the estuary during the wet-season floods. In addition, Lakefield National Park staff reported 'literally thousands' of $H$. littoralis propagules floating on the river 20 to $30 \mathrm{~km}$ downstream from the mouth in March 1999, i.e. the late wet season (J. Barton pers. comm.), when the strongest floods were over. Within $1 \mathrm{wk}$ of the heaviest rainfall, freshwater discharge decreases (J. Barton pers. comm.); saline waters rapidly intrude upstream, and an initially steep axial salinity gradient builds up (see Figs. 4a \& 5a), axial convergences form, and move those propagules remaining in the estuary upstream.
From the data presented it is apparent that any floating matter is subject to an upstream drift in the same way, regardless of type and size. Although propagules of different species display distinct differences in shape and size, they share a similar drift path. (It is interesting that the 'sail' of Heritiera littoralis seeds, developed to enhance wind-driven dispersal [Tomlinson 1986, Lovelock 1993], seems to play a negligible role in the dispersal within the estuary.) Hence, no tidal sorting of propagules as proposed by Rabinowitz (1978a) seems to occur in an estuary with axial convergences. Propagules are also not delivered to all portions of the intertidal zone, as previously suggested by Smith (1992), but rather to the furthest extension of the latter.

\section{Implications for establishment of propagules}

Successful development of a propagule to a mature tree is negatively correlated to its mortality, which is

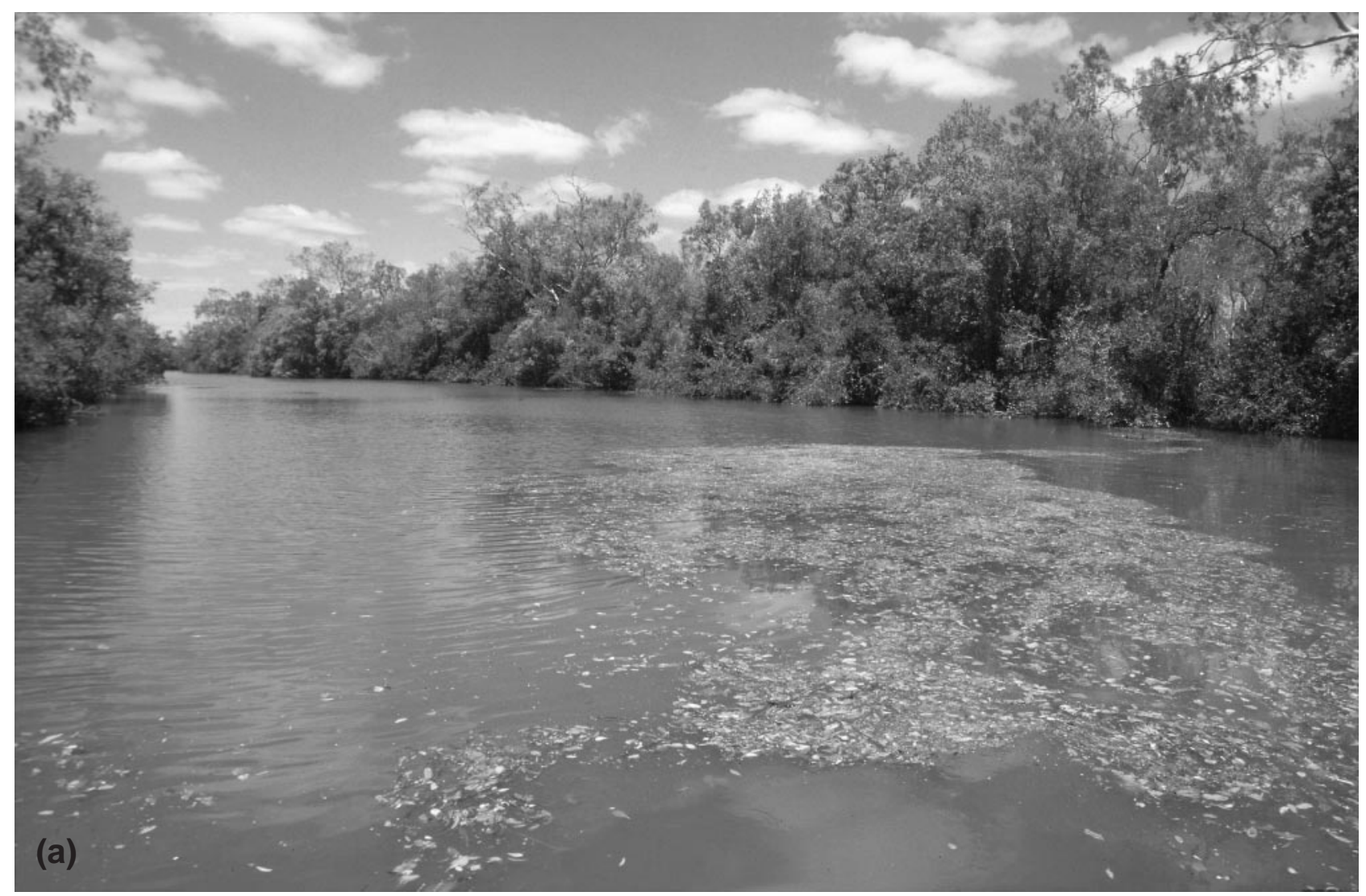

Fig. 8. (Above and following page.) Trapping of a large number of propagules (a) at the upstream end of the axial convergence (b) and further upstream, in terrestrial vegetation zones. The photo in (b) was taken at Site A (Fig. 1) 


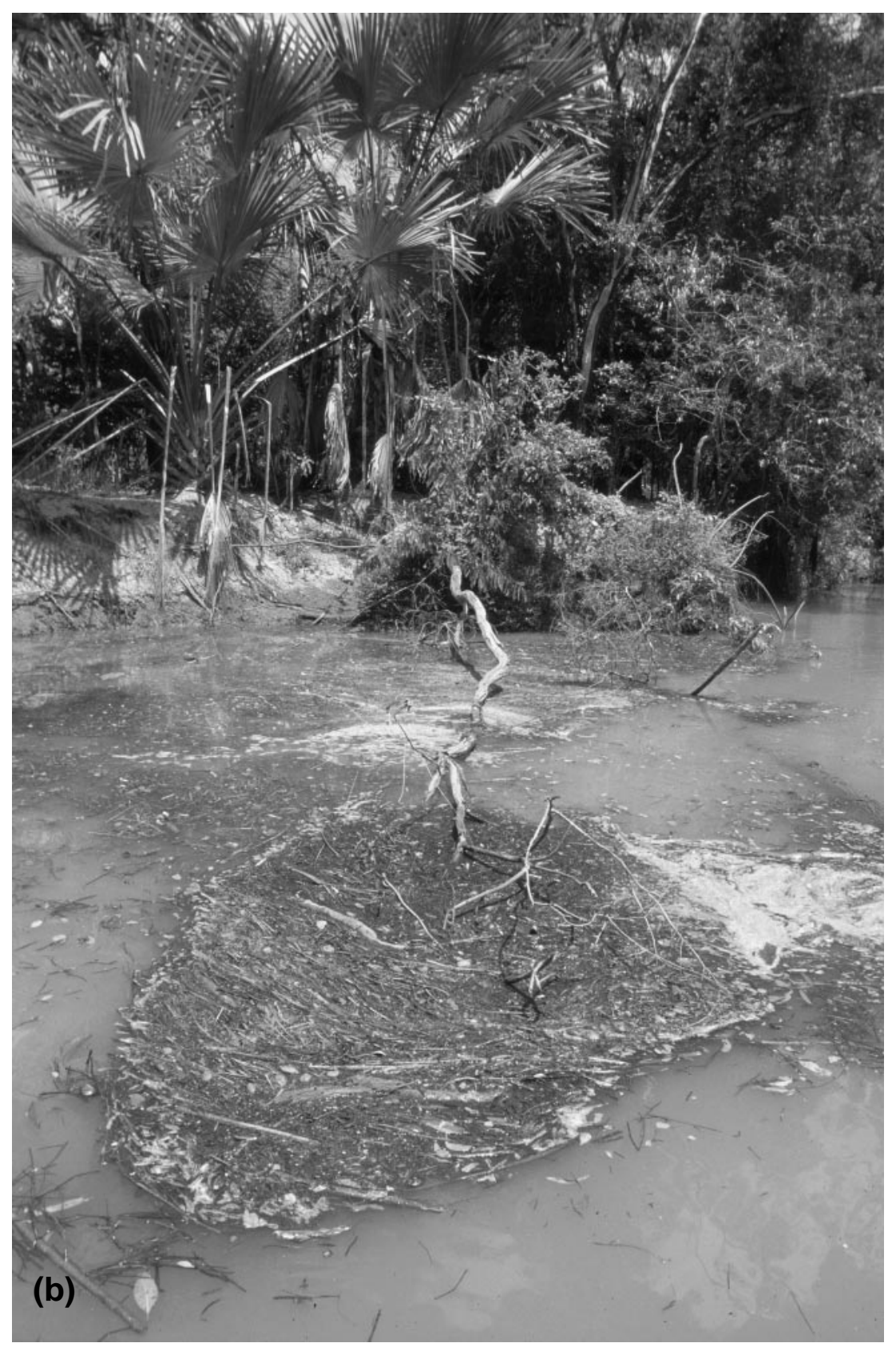

Fig. 8 (continued)

largely dependent on 3 factors: (1) its longevity; (2) its being stranded in suitable/unsuitable areas or substrates; (3) injury through or attachment of marine organisms and subsequent sinking (Saenger 1982). Therefore, it is interesting to compare 'timetables' of hydrodynamic trapping and longevity. With the exception of Rhizophora stylosa, the investigated propagules have a longevity of $>2$ mo. The long-lived Bruguiera gymnorrhiza, Xylocarpus mekongensis and Heritiera littoralis propagules accumulate at the upstream end of the convergence in large numbers in comparison with the numbers trapped in the convergence, whereas the difference in numbers of $R$. stylosa propagules at the upstream end versus in convergence is not as pronounced (Fig. 5b). This is likely to be due to the loss of $R$. stylosa propagules through sinking. Long-lived propagules are moved into upstream parts of the estuary, where salinity is close to zero. In the dry season, 
this furthest extension of the convergence lies in zones of terrestrial vegetation (see above and Fig. 5b,c), an area that is an unsuitable habitat for mangroves, because of the low salinity prevailing throughout the year. Short-lived propagules are likely to die and sink in the process of being transported upstream, unless they colonize the banks of the river, which is a habitat obviously very restricted in space, and which also is ecologically not suitable for many species. In conclusion, hydrodynamic trapping conflicts with the temporal and spatial requirements of propagules to 'find' a habitat suitable for development.

\section{Implications for forest structure along the estuary}

A differential dispersal of propagules could not be observed. Therefore it is unlikely that the net upstream drift of propagules by hydrodynamic means effects the zonation of species, which is widely regarded as a response to prevailing gradients of ecological variables (e.g. Smith 1992). However, revegetation of mangroves in disturbed areas may be influenced by the described trapping of propagules in estuarine waters. Species growing downstream from a forest gap can potentially recolonize the area, because their propagules are moved upstream towards the gap and have a fair chance of stranding on the banks at the location of the gap at ebb tides. It is noteworthy that the distribution of the large Rhizophora stylosa forest on the Normanby River extends ca $25 \mathrm{~km}$ into the estuary, whereas more or less isolated stands account for the occurrence of this species for up to $35 \mathrm{~km}$. Some of those stands might have been established in forest gaps due to the availability of a large number of propagules throughout the year. On the other hand, gaps high on the banks and far from the water's edge are likely to be recolonized by surrounding species rather than by trees from other areas. Propagules are unlikely to enter a forest high on the bank, because they are located in midstream at high-water level and on the bank at lowwater level (Ridd et al. 1998). However, care has to be taken with such interpretation. In any location, i.e. in an existing forest or in a 'new' location like a forest gap, a specific combination of ecological conditions is necessary for successful development of a species (Smith 1992, Clarke 1995, McKee 1995). We agree with McGuinness (1997), who suggested that this regeneration niche concept understates the importance of availability of propagules prior to establishment: 'Where no seed gets to, a tree won't grow, no matter what the conditions are'. This simple rule is widely applied in the concept of 'supply-side ecology' (Underwood \& Fairweather 1989). It also has to be considered in the light of modern forest ecology, whereby trees are grouped into pioneer or climax groups, depending on their reproductive strategies (e.g. Whitmore 1989). Generally, mangroves, and in particular Rhizophora spp., are regarded as pioneers (Saenger 1982, Tomlinson 1986), although different views exist on the relative ability of a species to act as pioneer (Smith 1992, Clarke 1995). Revegetation and species diversity in forest gaps might therefore be constrained by propagule availability which, in turn, is restricted by trapping in an axial convergence.

The described density-driven axial convergence is unlikely to be a local phenomenon occurring only in the Normanby River estuary. Trapping of propagules in upstream parts of estuaries is predicted to occur in many other (large) estuaries with sufficiently high axial salinity gradients.

\section{Conclusion}

In the Normanby River estuary, a density-driven axial convergence, occurring throughout the tropical dry season, transports mangrove propagules and other floating matter upstream. A net upstream drift of representative drogues of $3.2 \mathrm{~km} \mathrm{~d}^{-1}$ has been measured, and mangrove propagules have been found to be trapped in large numbers by the axial convergence and turbulences in freshwater upstream from mangrove vegetation, an unsuitable area for successful establishment of mangroves. All buoyant matter drifts upstream in the same manner. No differential trapping of buoyant propagules occurs, therefore the trapping mechanism is not likely to have an effect on mangrove zonation. However, revegetation and species richness in forest gaps along an estuary might be constrained by selective propagule availability which, in turn, is influenced by trapping in an axial convergence. In general, hydrodynamic trapping conflicts with the temporal and spatial requirements of propagules to 'find' a habitat suitable for development.

Acknowledgements. John Barton's (Lakefield National Park, Queensland National Park and Wildlife Service) invaluable advice, keen observations and interest in our work are gratefully acknowledged. Simone Bettinger, Severine Thomas, Jamie Bunt and Dr Piers Larcombe shared the fun and fascination of fieldwork on the river. T.S. thanks Dr John Bunt for providing access to a large data base on mangrove populations held at the Australian Institute of Marine Science, and furthermore for the fruitful discussions during his visit to Townsville in 1998. Thanks are also due to Dr Jeff Miller (Queensland National Park and Wildlife Service) for demonstrating the 'marginal' differences between 'specimen collection' of mangrove propagules and crocodiles. The Australian Bureau of Meteorology provided rainfall data, and the Department of Primary Industries issued a permit for collection of mangrove propagules. T.S.'s visit to James Cook Uni- 
versity was made possible by the Deutscher Akademischer Austauschdienst, Germany, and the project was funded by James Cook University and Australian Research Council. Dr Peter Clarke's valuable comments on the manuscript are gratefully acknowledged.

\section{LITERATURE CITED}

Ball MC (1998) Mangrove species richness in relation to salinity and waterlogging: a case study along the Adelaide River floodplain, northern Australia. Glob Ecol Biogeogr Lett 7:73-82

Boto KG, Wellington J (1984) Soil characteristics and nutrient status in northern Australian mangrove forests. Estuaries 7:61-69

Boto KG, Bunt JS, Wellington J (1984) Variation in mangrove forest productivity in Northern Australia and Papua New Guinea. Estuar Coast Shelf Sci 19:321-329

Bryce S, Larcombe P, Ridd P (1998) The relative importance of landward-directed tidal sediment transport versus freshwater flood events in the Normanby River estuary, Cape York Peninsula, Australia. Mar Geol 149:55-78

Bunt JS, Stieglitz T (1999) Indicators of mangrove zonality: the Normanby River, N.E. Australia. Mangroves Salt Marshes 3:177-184

Bunt JS, Williams WT, Clay HJ (1982) River water salinity and the distribution of mangrove species along several rivers in North Queensland. Aust J Bot 30:401-412

Chapman VJ (1976) Mangrove vegetation. Cramer, Vaduz

Clarke PJ (1993) Dispersal of grey mangrove (Avicennia marina) propagules in southeastern Australia. Aquat Bot 45:195-204

Clarke PJ (1995) The population dynamics of the mangrove shrub Aegiceras cornilatum (Myrsinaceae): fecundity, dispersal, establishment and population structure. Proc Linn Soc NSW 115:35-44

Clarke PJ, Kerrigan RA, Westphal CJ (2001) Dispersal potential and early growth in 14 tropical mangroves: do early life history traits correlate with patterns of distribution? $\mathrm{J}$ Ecol (in press)

de Lange WP, de Lange PJ (1994) An appraisal of factors controlling the latitudinal distribution of mangrove (Avicennia marina var. resinifera) in New Zealand. J Coast Res 10: $539-548$

Duke NC (1992) Mangrove floristics and biogeography. In: Robertson AI, Alongi DM (eds) Tropical mangrove ecosystems. American Geophysical Union, Washington, DC, p 63-100

Lovelock C (1993) Field guide to the mangroves of Queensland. Australian Institute of Marine Science, Townsville

Lugo AE, Zucca CP (1977) The impact of low temperature stress on mangrove structure and growth. Trop Ecol 18: 149-161 (Bull Int Soc Trop Ecol: C)

Macnae W (1969) Zonation within mangroves associated with estuaries in North Queensland. In: Lauff GE (ed) Estuar-

Editorial responsibility: Otto Kinne (Editor),

Oldendorf/Luhe, Germany ies. American Association for the Advancement of Science, Washington, DC, p 432-441

McGuinness KA (1997) Dispersal, establishment and survival of Ceriops tagal propagules in a north Australian mangrove forest. Oecologia 109:80-87

McKee KL (1995) Seedling recruitment patterns in a Belizean mangrove forest: effects of establishment ability and physico-chemical factors. Oecologia 101:448-460

Murray DR (1986) Seed dispersal by water. In: Murray DR (ed) Seed dispersal. Academic Press, Sydney, p 49-85

Nunes RA, Simpson JH (1985) Axial convergence in a wellmixed estuary. Estuar Coast Shelf Sci 20:637-649

Rabinowitz D (1978a) Early growth of mangrove seedlings in Panama, and an hypothesis concerning the relationship of dispersal and zonation. J Biogeogr 5:113-133

Rabinowitz D (1978b) Dispersal properties of mangrove propagules. Biotropica 10:47-57

Ridd PV, Stieglitz T, Larcombe P (1998) Density-driven secondary circulation in a tropical mangrove estuary. Estuar Coast Shelf Sci 47:621-632

Ridley HN (1930) The dispersal of plants throughout the world. Reeves, Ashford, Kent

Robinson Swift M, Fredriksson DW, Celikkol B (1996) Structure of an axial convergence zone from acoustic Doppler profiler measurements. Estuar Coast Shelf Sci 43:109-122

Saenger P (1982) Morphological, anatomical and reproductive adaptions of Australian mangroves. In: Clough BF (ed) Mangrove ecosystems in Australia: structure, function and management. Australian National University Press, Canberra, p 153-191

Smith TJ III (1988) Structure and succession in tropical, tidal forests: the influence of seed predators. Proc Ecol Soc Aust 15:203-211

Smith TJ III (1992) Forest structure. In: Robertson AI, Alongi DM (eds) Tropical mangrove ecosystems. American Geophysical Union, Washington, DC, p 101-136

Smith TJ III, Duke NC (1987) Physical determinants of interestuary variation in mangrove species richness around the tropical coastline of Australia. J Biogeogr 14:9-19

Tomlinson PB (1986) The botany of mangroves. Cambridge University Press, Cambridge

Underwood AJ, Fairweather PG (1989) Supply-side ecology and benthic marine assemblages. Trends Ecol Evol 4: $16-20$

van der Pijl L (1969) Principles of dispersal in higher plants. Springer-Verlag, Berlin

Watson JG (1928) Mangrove forests of the Malay Peninsula. Malay Forest Rec 6:1-275

Wells AG (1995) Groupings of tidal river systems in northern Australia based on mangrove species. Proc Linn Soc NSW 115:135-148

Whitmore TC (1989) Canopy gaps and the two major groups of forest trees. Ecology 70:536-538

Wolanski E (1986) An evaporation-driven salinity maximum zone in Australian tropical estuaries. Estuar Coast Shelf Sci 22:415-424

Submitted: March 14, 2000; Accepted: June 27, 2000

Proofs received from author(s): January 22, 2001 